\title{
GENETIC DIVERSITY AND FRAGMENTATION OF ASPIDOSPERMA QUEBRACHO-BLANCO (APOCYNACEAE) NATURAL HABITATS, CONSERVATION ISSUES IN CHACO FOREST AND SAVANNA BIOMES
}

\author{
Thomáz S. Guerreiro Botelho ${ }^{1,2}$ (D), Gecele Matos Paggi ${ }^{1,2}$ (D) \& Maria Ana Farinaccio ${ }^{2,3}$
}

\begin{abstract}
${ }^{1}$ Laboratório de Genética, Campus do Pantanal, Universidade Federal de Mato Grosso do Sul, 1270 Rio Branco Ave. 79304-902, PO Box 252, Corumbá-MS, Brazil.

${ }^{2}$ Programa de Pós-Graduação em Biologia Vegetal, Instituto de Biociências, Universidade Federal de Mato Grosso do Sul, Costa e Silva Ave. 79070-900, PO Box 549, Campo Grande-MS, Brazil; gecele.paggi@ufms.br (author for correspondence). ${ }^{3}$ Laboratório de Botânica, Herbário COR, Campus do Pantanal, Universidade Federal de Mato Grosso do Sul, Corumbá-MS, Brazil.
\end{abstract}

\begin{abstract}
Botelho, T. S. G.; G. M. Paggi \& M. A. Farinaccio. 2021. Genetic diversity and fragmentation of Aspidosperma quebracho-blanco (Apocynaceae) natural habitats, conservation issues in Chaco forest and savanna biomes. Darwiniana, nueva serie 9(1): 115-129.

The present study analyses the first data on genetic diversity of A. quebracho-blanco with the fragmentation of its natural habitat, supporting conservation strategies such as the definition of priority areas for conservation. DNA was extracted from 25 individuals of five populations of $A$. quebracho-blanco from Argentina, Paraguay, and Brazil. Six ISSR primers were used to characterize the genetic diversity and structure of this species. The genotypes were grouped according to a distance matrix, considering the genetic diversity indices of Nei (He), Shannon (H'), polymorphic information content (PIC), and heterozygosis (H). The populations showed an average genetic diversity that ranged from 0.09 to 0.15 for the Shannon index and from 0.19 to 0.31 for the Nei index; the Mantel test was not significant $\left(r^{2}=0.25, P=0.106\right)$. The results obteined for the sampled populations reveal that conservation units are indispensable for conserving the species genetic resources. In addition, it would be essential to construct a germplasm bank for the Cordoba (Argentina) population, which is a population with high genetic diversity in a region of lower fragmentation compared to other regions evaluated, to ensure the conservation of A. quebracho-blanco.
\end{abstract}

Keywords. Conservation unit; deforestation; dry forests; espinilho fields; ISSR.

Resumen. Botelho, T. S. G.; G. M. Paggi \& M. A. Farinaccio. 2021. Diversidad genética y fragmentación de hábitats naturales de Aspidosperma quebracho-blanco (Apocynaceae), problemas de conservación en los biomas de bosque y sabana chaqueños. Darwiniana, nueva serie 9(1): 115-129.

El presente estudio analiza los primeros datos de diversidad genética con la fragmentación del hábitat natural de $A$. quebracho-blanco, apoyando estrategias de conservación como la definición de áreas prioritarias para la conservación. Se extrajo ADN de 25 individuos de cinco poblaciones de A. quebracho-blanco de Argentina, Paraguay y Brasil. Se utilizaron seis "primers" de ISSR para caracterizar la diversidad y estructura genética de esta especie. Los genotipos se agruparon de acuerdo con una matriz de distancia, considerando los índices de diversidad genética de Nei (He), Shannon (H'), contenido de información polimórfica (PIC) y heterocigosis $(\mathrm{H})$. Las poblaciones estudiadas presentaron una diversidad genética promedio comprendida en un rango de 0,09 a 0,15 para el índice de Shannon y de 0,19 a 0,31 para el índice de Nei, y la prueba de Mantel no fue significativa $\left(\mathrm{r}^{2}=0,25, \mathrm{P}=0,106\right)$. Los resultados sobre las poblaciones muestreadas revelan que las unidades de conservación son indispensables para conservar los recursos genéticos de la especie. Además, sería fundamental construir un banco de germoplasma para la población de Córdoba (Argentina), una población con alta diversidad genética en una región de menor fragmentación que en otras regiones, en la cual se pueda garantizar la conservación de A. quebracho-blanco.

Palabras claves. Bosques secos; campos de espinillo; deforestación; ISSR; unidad de conservación. 


\section{INTRODUCTION}

Currently, the Chaco vegetation is undergoing widespread and increasing desertification, resulting from the exploitation of natural resources, mainly from deforestation (Pasig, 2005). Past changes, aggravated by the loss of tree cover since 2000 and agricultural expansion, have made Chaco deforestation rates one of the highest in the world (Hansen et al., 2013; Vallejos et al., 2015; Baumann et al., 2017). This situation poses challenges to the Chaco region's remnants, as fragmentation may affect the genetic diversity of populations (Hamrick, 2004).

In the past two decades, the significant changes of landscape and the evolutionary dynamics of natural populations under fragmentation have been studied in the tropics but mainly concerning rainforests (Jakovac et al., 2015), particularly in studies of adaptation, eco-evolutionary dynamics, and fragments (Hill et al., 2011; Lôbo et al., 2011; Taubert et al., 2018). Thus, most of the Chaco forest and savanna biomes, and other biogeographic regions with similar phytophysiognomies, are not considered in such studies but are indispensable for understanding the effects of fragmentation on species conservation and speciation process in the region (Werneck 2011; Hughes et al., 2013).

The effects of habitat fragmentation are documented as causing inbreeding and reducing the gene flow in natural populations, accelerating the reduction and extinction of these populations by reproductive isolation (Young \& Boyle, 2000). Moreover, populations are at risk of compromising the colonization process in other areas due to decreased genetic variability by inbreeding (Young \& Boyle, 2000; Schneider et al., 2003). These characteristics are crucial for the development and survival of individuals after possible regeneration and may determine a species' population structure (Medeiros et al., 2007).

When exposed to disturbance, natural forest populations tend to restructure as they are modified, restoring breeding processes such as pollination, seed dispersal, and seedling recruitment (Cullen Júnior et al., 2006), and genetic variability, mainly through gene flow, which is necessary for the maintenance of populations (Futuyma, 1992).
However, even if the identity and population function are maintained (Walker et al., 2004), the original genetic structure's recovery is not guaranteed, as genetic diversity may vary if populations are persistent or colonizing.

Aspidosperma quebracho-blanco Schltdl. (Apocynaceae) is characteristic of the Chaco environment in Argentina, Brazil, Bolivia, Paraguay, and Uruguay (Marcondes-Ferreira \& Kinoshita, 1996; Galvani \& De Moura, 2003; Jørgensen et al., 2014). This species has a history of large-scale logging due to the presence of tannin in its wood, used in the manufacture of chemical products and leather tanning. These features motivated the installation of industries in the Chaco region, threatening the natural populations of A. quebracho-blanco (Hueck, 1955; Bandeira, 1998). Habitat disturbance and the restricted distribution of species are characteristics that may contribute to the evolution of self-compatibility systems, which initially may lead to low genetic variability and, consequently, niche amplitude, a factor of significant influence on the occupation of new areas (Lowry \& Lester, 2006). Such conditions may be occurring in A. quebracho-blanco populations due to the fragmentation of their natural habitats.

Genetic diversity assessments of species threatened by habitat fragmentation have shown promising results when used in conservation strategies and the maintenance of natural populations (Ferreira \& Grattapaglia, 1998; Finger et al., 2014). Genetic analysis provides data for better understanding patterns of the structure and distribution of genetic variability, which are important indicators for understanding evolutionary processes in natural populations. Studies using genetic data may also suggest areas for conserving a significant portion of genetic diversity, indicating the need for the creation of units of conservation. (Montagna et al., 2012).

Advances in molecular biological studies, such as DNA molecular markers for endangered species, facilitate conservation strategies and the use of genetic resources more appropriately (Avise, 2010; Frankham, 2010). Thus, conservation strategies that use these molecular markers can quantify the potential genetic resources available in natural populations, allowing us to elucidate and predict future genetic events, as well as connection points between populations and their evolutionary events (Cruz et al., 2011; Rajwant et al., 2011). 
Table 1. Data of sampled populations of Aspidosperma quebracho-blanco. Geographic origins and voucher information from each population analysed in the present study.

\begin{tabular}{|c|c|c|c|c|}
\hline Population & ID & Coordinates & Voucher & Herbarium \\
\hline Barra do Quaraí (Brazil) & BAQ & $30^{\circ} 11^{\prime} 31.7^{\prime \prime} \mathrm{S}, 57^{\circ} 31^{\prime} 21.3^{\prime \prime} \mathrm{W}$ & Farinaccio \& Uchôa 1013 & $\mathrm{CGMS} / \mathrm{COR}$ \\
\hline Cordoba (Argentina) & $\mathrm{COB}$ & $31^{\circ} 22^{\prime} 5.46^{\prime \prime} \mathrm{S}, 65^{\circ} 28^{\prime} 08.04^{\prime \prime} \mathrm{W}$ & Cocucci 5680 & CORD \\
\hline Filadelfia (Paraguay) & FIL & $22^{\circ} 36^{\prime} 03.1{ }^{\prime \prime} \mathrm{S}, 59^{\circ} 56^{\prime} 43.3^{\prime} \mathrm{W}$ & Vogt \& Farinaccio 1709 & FACEN \\
\hline Formosa (Argentina) & FOR & $24^{\circ} 67^{\prime} 6.74^{\prime \prime} \mathrm{S}, 60^{\circ} 60^{\prime} 07.65^{\prime \prime} \mathrm{W}$ & Farinaccio 1015 & CGMS \\
\hline Porto Murtinho (Brazil) & PMU & 21'39’14.83”S, 5749’51.02”W & Farinaccio 980 & $\mathrm{CGMS} / \mathrm{COR}$ \\
\hline
\end{tabular}

Among the types of molecular markers used in population genetics analysis, ISSR (Inter Simple Sequence Repeats) has been increasing in popularity due to its effectiveness in detecting polymorphisms and genome abundance, low cost, and because it is a relatively simple technique (Gupta et al., 1994; Santana et al., 2011; Ng \& Tan, 2015). Although ISSR markers have some limitations regarding low reproducibility and homology of co-migrating amplification products, these markers also use a single primer to obtain fragments and access germplasm fingerprinting of cultivated and native species, helping to elucidate evolutionary relationships among species (Manel et al., 2003; Faleiro, 2007; Amom \& Nongdam, 2017). The specifics of each population obtained from molecular markers can be quantitatively related to geographical characteristics (Manel et al., 2003). Thus, this study aimed to present initial genetic structuring data of $A$. quebracho-blanco natural fragmented populations to suggest priority populations and guidelines, and for conservation and management efforts.

\section{MATERIALS AND METHODS}

\section{Study area and sampling}

Collection expeditions were carried out on three out of five known distribution areas of Aspidosperma quebracho-blanco (Argentina, Brazil, and Paraguay). All collected material was deposited in the herbaria of the Federal University of Mato Grosso do Sul (CGMS and COR), Cordoba Botanical Museum (CORD), and National University of Asunción (FACEN) (Table 1; acronyms following Thiers, 2020).
The collected leaves were stored in silica gel for rapid dehydration (Chase \& Hills, 1991). Overall, 25 individuals were collected, five samples from five populations: BAQ (Barra do Quaraí, Brazil), COB (Cordoba, Argentina), FIL (Filadelfia, Paraguay), FOR (Formosa, Argentina), and PMU (Porto Murtinho, Brazil) (Fig. 1).

The COB, FIL, FOR, and PMU populations were located in the Chaco area, an environment that has been disturbed in the past by logging and pasture clearing (Vallejos et al., 2015). In this biogeographic region, there is a more significant number of A. quebracho-blanco populations, unlike in Barra do Quaraí (Brazil), where there is only one population. The phytophysiognomy present in the Barra do Quaraí municipality is predominantly Steppe Savanna, with many fields of "espinilhos". "Espinilho" is the popular name given to Vachellia (=Acacia) caven (Molina) Seigler \& Ebinger, one of the most representative tree species in the region (Galvani \& De Moura, 2003).

\section{DNA extraction and loci selection}

Genomic DNA was extracted from leaves according to the protocol of Doyle and Dickson (1987) with changes to the amount of isopropanol $(750 \mu \mathrm{L})$ after collecting the aqueous phase. Extracted DNA was quantified on a $1 \%$ agarose gel stained with SyberGold TM (Invitrogen $\AA$, Thermo Fisher Scientific, Waltham, Massachusetts) and compared to DNA of phage $\lambda$.

Thirty-three ISSR primers were tested, 30 of which were developed by the University of British Columbia Biotechnology Laboratory (UBCBL), named UBC primers (NAPS, 2019), and three others by Al-Otaibi (2008), named Primers Numbers 7, 12 and 16 (Table 2). 

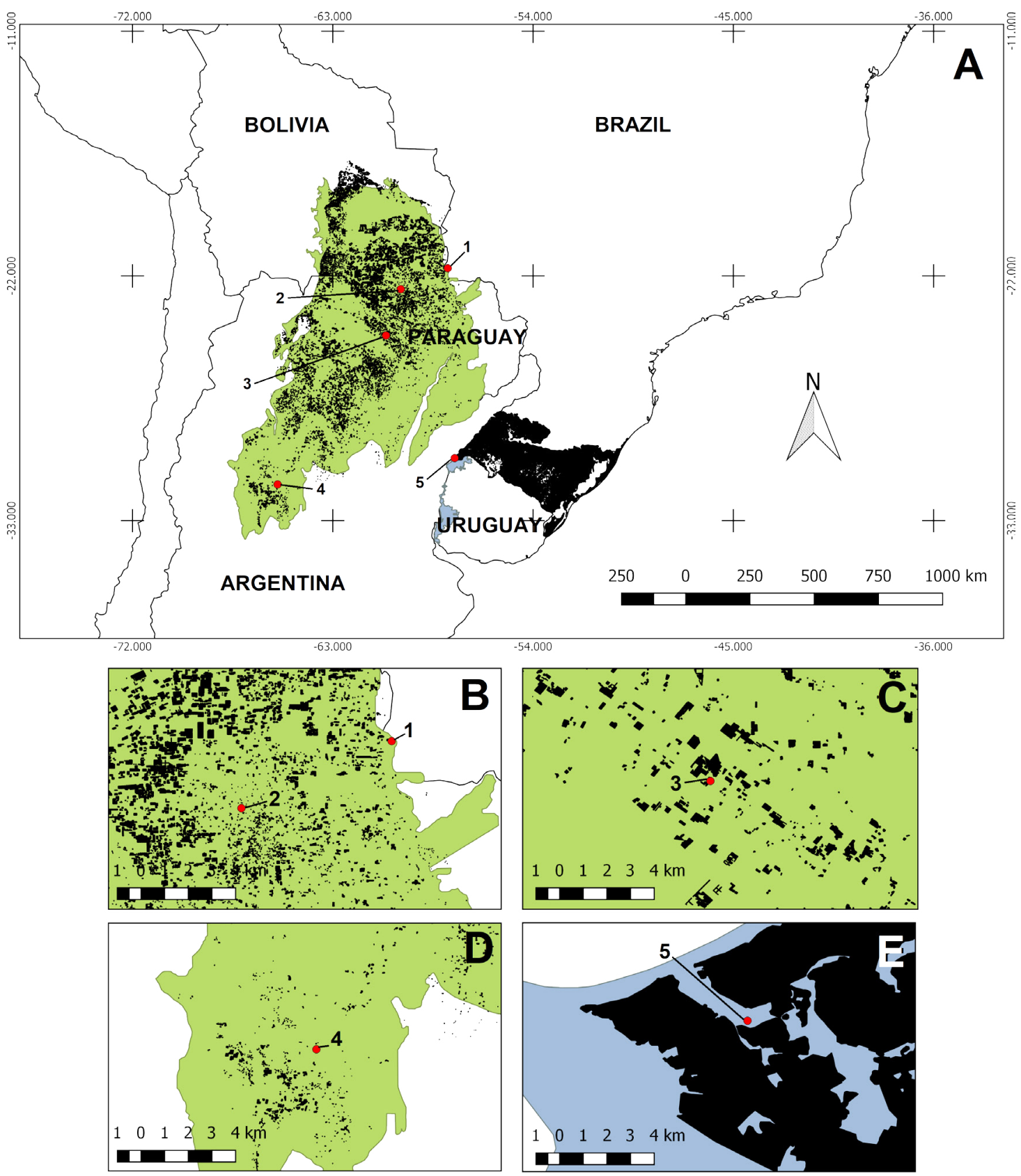

\section{A. quebracho-blanco populations \\ Chaco \\ Ecological systems of Uruguayan Savannas \\ Anthropogenic impacts near the sampled populations}

Fig. 1. Distribution map of the sampled populations in the Chaco vegetation area, Uruguayan Savannas' ecological systems, and anthropization nearby. A, mapping of anthropization near the Steppe Savanna and deforestation in the Chaco, related to the sampled populations: PMU (1); FIL (2); FOR (3); COB (4) and BAQ (5). B-E, detail of impacts close to the sampled populations. Map made with QGIS ${ }^{8} 3.0$ software (QGIS, 2011) based on Veloso et al. (1991), Olson et al. (2001), and Hasenack et al. (2010). Color version at http://www.ojs.darwin.edu.ar/index.php/darwiniana/article/view/932/1213 
Table 2. Amplification test of ISSR primers in A. quebracho-blanco.

\begin{tabular}{|c|c|c|c|}
\hline Primers & Amplification & $\begin{array}{l}\text { Sequence } \\
5,-3,\end{array}$ & Reference \\
\hline Primer No. 12 & $\mathrm{~F}$ & TCСТCСТCСТCСТCCGT & \multirow{3}{*}{ Al-Otaibi (2008) } \\
\hline Primer No. 16 & + & ACACACACACACACACYT & \\
\hline Primer No.7 & $+*$ & AGACAGACAGACAGACGC & \\
\hline UBC 807 & - & AGAGAGAGAGAGAGAGT & \multirow{30}{*}{$\begin{array}{l}\text { NAPS Unit Standard Primers } \\
\qquad(2006)\end{array}$} \\
\hline UBC 808 & $+*$ & AGAGAGAGAGAGAGAGC & \\
\hline UBC 810 & + & GAGAGAGAGAGAGAGAT & \\
\hline UBC 811 & - & GAGAGAGAGAGAGAGAC & \\
\hline UBC 812 & - & GAGAGAGAGAGAGAGAA & \\
\hline UBC 813 & - & СТСТСТстСТстСТстT & \\
\hline UBC 815 & - & стстСтСТстстСтстG & \\
\hline UBC 818 & - & CACACACACACACACAG & \\
\hline UBC 820 & - & GTGTGTGTGTGTGTGTC & \\
\hline UBC 823 & $\mathrm{~F}$ & ТСТСТСТСТСТСТСТСС & \\
\hline UBC 824 & - & ТСТСТСТСТСТСТСТCG & \\
\hline UBC 827 & - & ACACACACACACACACG & \\
\hline UBC 834 & + & AGAGAGAGAGAGAGAGYT & \\
\hline UBC 835 & - & AGAGAGAGAGAGAGAGYC & \\
\hline UBC 836 & + & AGAGAGAGAGAGAGAGYA & \\
\hline UBC 840 & + & GAGAGAGAGAGAGAGAYT & \\
\hline UBC 841 & + & GAGAGAGAGAGAGAGACTC & \\
\hline UBC 842 & $+*$ & GAGAGAGAGAGAGAGAYG & \\
\hline UBC 844 & - & CTCTCTCTCTCTCTCTRC & \\
\hline UBC 845 & $\mathrm{~F}$ & CTCTCTCTCTCTCTCTRG & \\
\hline UBC 848 & - & CACACACACACACACARG & \\
\hline UBC 850 & - & GTGTGTGTGTGTGTGTYC & \\
\hline UBC 851 & - & GTGTGTGTGTGTGTGTYG & \\
\hline UBC 855 & $\mathrm{~F}$ & ACACACACACACACACCTT & \\
\hline UBC 856 & $+*$ & ACACACACACACACACYA & \\
\hline UBC 857 & $+*$ & ACACACACACACACACYG & \\
\hline UBC 866 & - & СТССТССТССТССТСстС & \\
\hline UBC 888 & $+*$ & BDBCACACACACACACA & \\
\hline UBC 889 & + & AGTCGTAGTACACACACACACAC & \\
\hline UBC 891 & - & HVHTGTGTGTGTGTGTG & \\
\hline
\end{tabular}

(+) Successful amplification; (+*) polymorphic loci used in population analysis; (-) Unsuccessful amplification; (F) weak amplifications; $\mathrm{R}=\mathrm{A}$ or $\mathrm{G} ; \mathrm{Y}=\mathrm{C}$ or $\mathrm{T} ; \mathrm{B}=\mathrm{G}, \mathrm{T}$ or $\mathrm{C} ; \mathrm{D}=\mathrm{G}, \mathrm{A}$ or $\mathrm{T} ; \mathrm{H}=\mathrm{A}, \mathrm{C}$ or $\mathrm{T} ; \mathrm{V}=\mathrm{G}, \mathrm{C}$ or $\mathrm{A}$.

Amplifications were performed by PCR in $25 \mu \mathrm{L}$ reactions containing $\approx 30 \mathrm{ng}$ DNA, $1 \mathrm{X}$ enzyme buffer, $2.0 \mathrm{mM} \mathrm{MgCl}^{2}, 0.15 \mathrm{mM}$ dNTP mix, 0.5 pmol ISSR primer, and $1 \mathrm{U}$ of Taq DNA polymerase (Go Taq, Promega (C), Madison, Wisconsin, United States), amplified in a Veriti 96-well thermocycler (Applied Biosystems, Foster City, CA, USA) using the conditions previously described (Ribeiro et al., 2013; Vieira et al., 2014). Amplified products were visualized on SyberGold ${ }^{\mathrm{TM}}$ stained $1.5 \%$ agarose gel (Invitrogen (C), Thermo Fisher Scientific, Waltham, Massachusetts) and 1X TBE under a $120 \mathrm{~mA}$ direct current. The molecular weight marker used was ladder $1 \mathrm{~Kb}$ (Invitrogen (C), Thermo Fisher Scientific, Waltham, Massachusetts), and the products were photographed with the incidence of blue light. 


\section{Genetic data analysis}

To characterize the genetic diversity of $A$. quebracho-blanco populations, polymorphic ISSR loci with the largest number of fragments and reasonable resolution, and therefore more information, were selected. The polymorphic loci obtained were observed and photographed on agarose gels for a categorical analysis in Image ${ }^{\circledR}$ software (Schneider et al., 2012). The collected data were used to construct a binary matrix based on the presence (1) and absence (0) of bands for all selected loci. The matrix was used to calculate the similarity matrix, considering the Jaccard index (Jaccard, 1908) as the arithmetic complement, with which genetic similarities were obtained within and between populations.

To establish a genotype grouping based on genetic similarity and construct a dendrogram, the unweighted pair group method (UPGMA) with the arithmetic mean was used (Sokal \& Michener, 1958). The distance matrix and the dendrogram were obtained using the Past 3.0 ${ }^{\circledR}$ program (Hammer et al., 2001). To analyse diversity within and among the studied populations, the Genes ${ }^{\circledR}$ program (Cruz, 2019) was used, estimating the following diversity parameters: Nei (He) genetic diversity (Nei, 1973), Shannon (H') index (Shannon, 1948), polymorphic information content (PIC) ranging from 0 to 0.5 in dominant markers (Botstein et al., 1980) and heterozygosis, which was obtained from binary data (Cruz, 2019). The hypotheses of genetic data being differentiated because of distance isolation were also tested, and a correlation was established between geographic data and genetic distance matrices $\left(\mathrm{F}_{S T} /\left(1-\mathrm{F}_{S T}\right)\right.$ by the Mantel test (Sokal \& Rohlf, 1995) using GenePop On the web 4.2 (Raymond \& Rousset, 1995).

\section{Identification of fragmented habitats by georeferencing collection areas}

The collected populations were represented cartographically using QGIS ${ }^{\circledR} 3.0$ software, with the Chaco areas and ecological systems of Uruguayan Savannalimitations previously defined by Veloso et al. (1991) and Hasenack et al. (2010).
The QGIS ${ }^{\circledR} 3.0$ software was also used to identify landscape degradation that could pose potential risks to the sampled populations, using cartographic objects and collection locations represented with Chaco deforestation areas line-type shapefiles (Guyra Paraguay, 2019) and anthropization near the "espinilho" fields ("Projeto Monitoramento do Desmatamento dos Biomas Brasileiros" - Deforestation Monitoring Project for Brazilian Biomes).

\section{RESULTS}

\section{Success of amplification and polymorphisms}

The amplified products presented good electrophoretic profiles, totalling 450 bands in the 200 to 5000 bp regions. Of the 33 primers tested in A. quebracho-blanco, 16 were amplified (48\%) (Table 2), with six selected loci presenting the best band patterns and polymorphisms under the conditions tested. In addition, 124 loci (two to six bands per population) were amplified, and of those, 37 polymorphisms (45.8\%) were identified, with an average of six polymorphisms per marker. Among the loci selected for diversity and similarity analyses, an average of 20 sequences per primer were observed: 22 sequences $(18.3 \%)$ in UBC 888, $21(17.5 \%)$ in UBC 808 and UBC 856,19 sequences $(15.8 \%)$ in primer No.7 and UBC 842 and, 18 sequences (15\%) in UBC 857.

\section{Population similarities and geographic correlations}

The coefficient values of the similarity matrix among populations ranged from 0.26 to 0.55 , with a mean of 0.41 ; the highest similarity was between the FIL and FOR populations. The UPGMA-based dendrogram between the analysed population genotypes separated PMU from the other populations and formed two more groups with similarity values higher than 0.51 . In branch number I, FOR and FIL populations were grouped, while in branch II a group with $\mathrm{COB}$ and BAQ was formed (Fig. 2).

Among the individuals sampled in different populations, the similarity matrix values ranged from 0.0 to 0.77 , with values between individuals from the same population ranging from 0.0 to 0.92 (Table 3 ). 


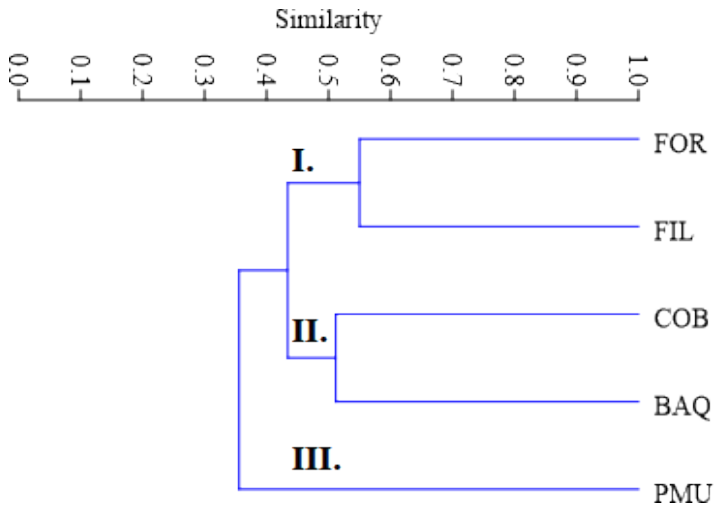

Fig. 2. UPGMA dendrogram of A. quebracho-blanco populations sampled, considering the Jaccard index as an arithmetic complement. Branch I: (FOR and FIL), Branch II: (COB and BAQ), Branch III (PMU).

Besides, according to the same criteria used for population analysis, the dendrogram of the 25 individuals analysed grouped representatives from different populations in close branches, with PMU being the population that presented the most distinct values of similarity among their individuals (Fig. 3). The Mantel test was not significant $\left(\mathrm{r}^{2}=0.25, \mathrm{P}=0.106\right)$, showing no association between genetic and geographic distances, indicating the absence of isolation by distance between the sampled locations.

\section{Genetic diversity}

The mean genetic diversity observed in the populations ranged from 0.09 to 0.15 for the Shannon index and from 0.19 to 0.31 for Nei diversity (Fig. 4). Allele frequency and heterozygosis showed relatively close values in the FOR, FIL, COB, and BAQ populations (Table 4), coinciding with the PIC patterns obtained with the accessions of the six markers tested (Table 5).

\section{Population distribution and environmental impacts}

The population distribution was concentrated, that is, closer to each other, under the dry Chaco area (north of the sampled phytophysiognomies), by passing the wet Chaco formations until reaching the disjunction of the savanna vegetation classified as "fields with espinilho in the Steppe Savanna" (Fig. 1A).

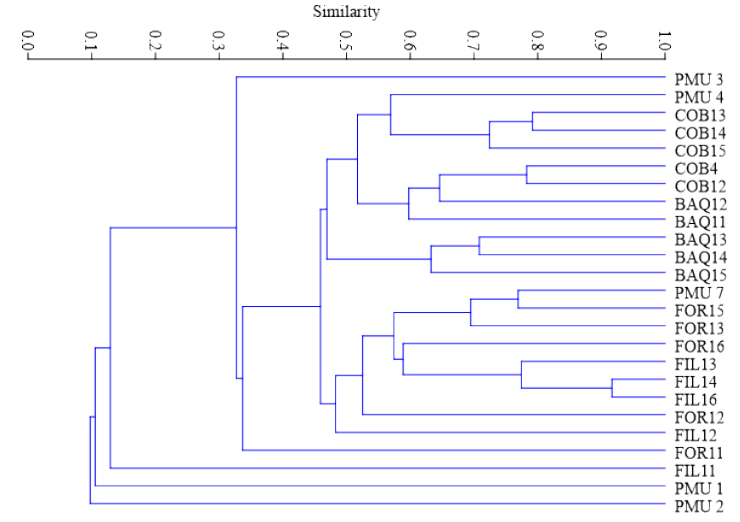

Fig. 3. UPGMA dendrogram of the 25 individuals of A. quebracho-blanco sampled, considering the Jaccard index as an arithmetic complement. Porto Murtinho, Brazil (PMU); Filadelfia, Paraguay (FIL); Formosa, Argentina (FOR); Cordoba, Argentina (COB); and Barra do Quaraí, Brazil (BAQ).

Higher environmental impacts were observed in the northern Chaco region and the Steppe Savanna than in other regions, where the populations of PMU, FIL, FOR, and BAQ are located (Fig. 1A-E). Georeferencing analyses at a smaller scale showed that the PMU population is in the Chaco border region also affected by deforestation; we also observed deforested regions very close to FIL and anthropized areas around Espinilho State Park (Brazil) in the BAQ population. However, the COB population was observed in conservation units within Chancaní Provincial Park's limits (Argentina).

\section{DISCUSSION}

In agreement with our study, other works that used molecular markers in species of Aspidosperma Mart. \& Zucc. showed the occurrence of values below $40 \%$ both in the number of amplified sequences and in the polymorphisms found by primers (Damasceno et al., 2011; Ferreira-Ramos et al., 2011; Zimback et al., 2011). In addition to this problem, which involves increased spending and time to obtain the results, DNA extraction from Aspidosperma leaves may be compromised due to the presence of 
a wide variety of alkaloids (Schumutz, 1960; Molinari \& Crochemore, 2001; Sahu et al., 2012), and polysaccharides (Freitas, 2008), which are responsible for possibly inhibiting Taq DNA polymerase in the PCR (Demeke \& Adams, 1992; Fang et al., 1992). Besides, added to the possibility of the occurrence of these substances in the DNA extraction, A. quebracho-blanco is a source species of tannins (Becker \& Makkar, 1999), compounds that precipitate with the DNA, thus degrading DNA quality and reducing the yield (Katterman \& Shattuck, 1983; Sarwat et al., 2006). Considering the possible implications of the DNA extraction and amplification procedures, we concluded that the products obtained were as expected and answered the proposed questions.

The spatial genetic structure observed in the A. quebracho-blanco natural populations represents the specific patterns of the spatial distribution of alleles and genotypes of individuals within populations (Vekemans \& Hardy, 2004). Genetic analysis showed that the distribution of A. quebracho-blanco genotypes did not occur randomly, since we verified the presence of individuals from nearby sites in equal branches on UPGMA dendrogram (Fig. 3), there is a need for a new larger sample of individuals so that distance isolation can definitely be suggested (Wright, 1943). It is possible that this feature can be associated with seed dispersal and seedling recruitment, which could be favoured in the PMU, FIL, and FOR populations since the arid and semiarid Chaco environment is characterized by rainfall scarcity (Riveros, 2005), which favours anemochory (Howe \& Smallwood, 1982), increasing the genetic similarity between these fragments due to gene flow via seeds (Hamrick et al., 1993). It is worth mentioning that this is a first approximation of the genetic structure of the sampled populations, with the need for an in-depth understanding of the eco-evolutionary processes of A. quebrachoblanco, whose limitations and inferences were not addressed by the ISSR techniques used here.

Geitonogamy is effective in A. quebrachoblanco, indicating that the species is selfcompatible (Lin \& Bernardello, 1999), a characteristic already reported in Apocynaceae species (Vieira \& Grabalos, 2003; Löhne et al., 2004; Darrault \& Schlindwein, 2005).

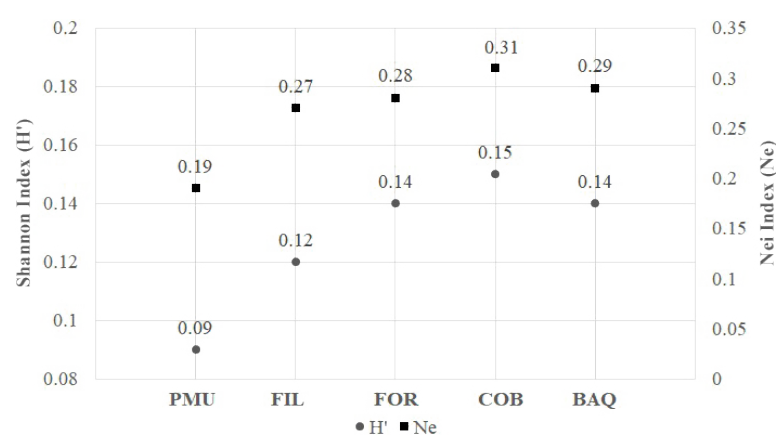

Fig. 4. Shannon index (H') and $\mathrm{Nei}(\mathrm{Ne})$ genetic diversity for the five native populations of A. quebracho-blanco. Porto Murtinho, Brazil (PMU); Filadelfia, Paraguay (FIL); Formosa, Argentina (FOR); Cordoba, Argentina (COB); and Barra do Quaraí, Brazil (BAQ).

The likelihood of foreign pollen arriving is only higher than the probability of self-pollination due to protandry and the position of the flowers (pending and sometimes in the horizontal position), characteristics that prevent self-fertilization (Lin \& Bernardello, 1999). However, variations in the reproductive system, like self-compatibility, may reduce heterozygosity (Pollak, 1987; Schoen \& Brown 1991) and possibly genetic diversity in natural populations (Hamrick \& Godt, 1996; Glémin et al., 2006). Such variation may also partly justify the values obtained for the frequency of alleles, low heterozygosis, and polymorphic information (PIC) in this study.

The establishment of autogamous populations is related to reductions in natural habitats, making cross-pollination difficult and guarantees significant survival of self-compatible mutants (Kaye, 1999). Similar effects have already been observed in plant reproductive systems from the Chaco Serrano (Aizen \& Feinsinger, 1994), as is the case of A. quebracho-blanco, whose reproductive system is characterized by limited moth nocturnal pollination, and moths' disorientation (Lin \& Bernardello, 1999).

The northern and northwestern portions of the Chaco are characterized by sudden changes in land cover (Caballero et al., 2014), where the lowest values of genetic diversity were observed in the population. Notably, the areas around the BAQ population have experienced 
T. S. G. BOTELHO ET AL. Genetic diversity of A. quebracho-blanco

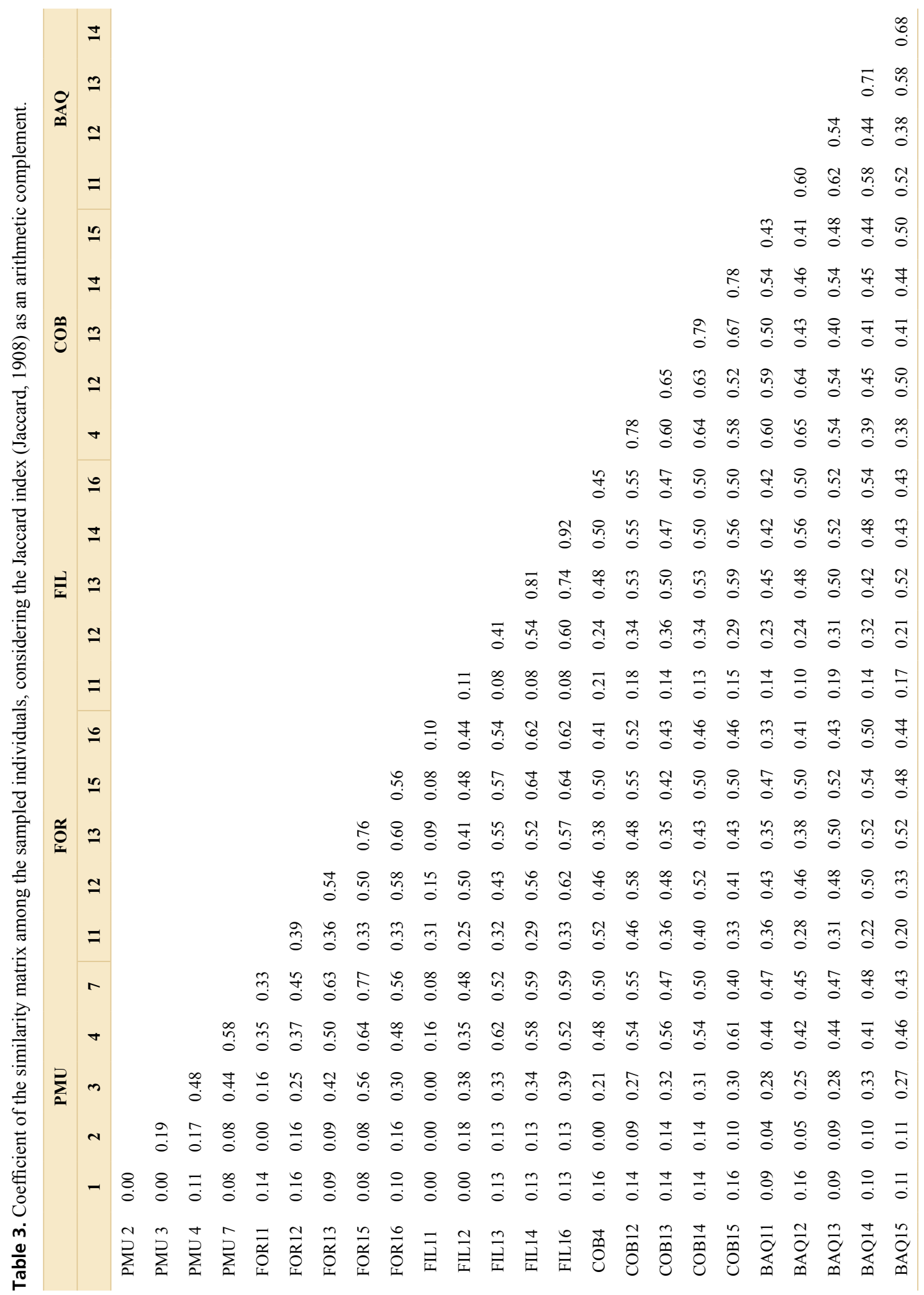


periods with variations in their hydromorphic soils due to degradation of surface horizons and natural regeneration of portions with signs of anthropogenic degradation (Da Cunha et al., 2001; Caldas et al., 2013). Thus, the sampled populations are surrounded by areas under anthropogenic impacts that threaten their current genetic diversity.

Likewise, the results presented here, habitat loss by anthropization, may also threaten other Apocynaceae tree species' genetic diversity. In a study with Hancornia speciosa Gomes in fragmented habitats, for example, the Shannon index $\left(\mathrm{H}^{\prime}\right)$ the Nei $(\mathrm{He})$ index values were 0.26 and 0.18 , respectively (Costa et al., 2015), which should be considered when establishing new conservation units of such populations with historical fragmentation and disturbance, which can make populations more vulnerable to the effects of genetic drift. Moreover, due to the greater likelihood of self-fertilization and interbreeding between closely related individuals, there is a possibility of inbreeding and border effects (Hartl \& Clark, 1997; Kageyama et al., 1998).

Environmental conditions in arid locations are critical factors for seedling establishment (Watson et al., 1997; Dodd \& Donovan, 1999). For regeneration of these regions, seedlings can be recruited from conservation units, as has been observed in seedlings from the Provincial Park Chancaní (Argentina) (Barchuk \& Díaz, 1999), where the population of the highest genetic diversity was observed (COB). These data show the importance of comparing the genetic information with other data, and it is possible to infer issues involving management, recovery of degraded areas, and distance parameters for germplasm collection to obtain higher levels of genetic variability from the sampled populations (Cloutier et al., 2007).

Conservation actions are primarily necessary for the Porto Murtinho (PMU) population, as the region has experienced the most fragmentation among the known Chaco formations in recent decades (Zak et al., 2004; Grau et al., 2005). Furthermore, there are indications that this population's genetic variability is similar to that in the other populations, showing similar genotypes.
Table 4. Frequency values of alleles obtained and heterozygosis $(\mathrm{H})$ for Aspidosperma quebracho-blanco populations sampled according to Genes ${ }^{\circledR}$ software (Cruz, 2019).

\begin{tabular}{cccc}
\hline Population & $\mathbf{f ( A )}$ & $\mathbf{f ( a )}$ & $\mathbf{H = 2} \mathbf{p q}$ \\
\hline PMU & 0.1 & 0.9 & 0.18 \\
FOR & 0.15 & 0.85 & 0.26 \\
FIL & 0.15 & 0.85 & 0.25 \\
COB & 0.17 & 0.83 & 0.28 \\
BAQ & 0.18 & 0.82 & 0.26 \\
\hline
\end{tabular}

Along with the geographical distribution, the remaining Chaco populations show greater genetic diversity values in a north-south diversity gradient, i.e., the starting point that can be considered for genetic diversification of $A$. quebracho-blanco probably is PMU. Therefore, the Porto Murtinho population may present priority conditions for creating conservation areas, ensuring gene flow and genetic diversity among the other fragments (Vieira \& Carvalho, 2008). Besides, it would be essential to construct a germplasm bank for the Cordoba (Argentina) population, which is a population with higher genetic diversity in a region of lower fragmentation than the other regions evaluated, in order to ensure the conservation of A. quebracho-blanco.

The estimates of genetic parameters have shown the need for the creation of protected areas for A. quebracho-blanco. Likewise, ecological aspects, such as the documentation of more than 200 kinds of insects associated with the availability of exudate extrafloral of this species (Lin \& Bernardello, 1999), also suggest special attention to their ecological relationships is needed, as habitat degradation due to urbanization may play a role in altering arthropod diversity (Gibb \& Dieter, 2002).

Our findings on the studied populations, considering the first genetic data and the geographical distribution of A. quebracho-blanco, indicate a possible threat to the genetic diversity of populations, an issue to be considered for the inclusion of A. quebracho-blanco on lists of threatened species, which are essential tools for planning conservation actions and programs (Mace et al., 2008). 
Table 5. Polymorphic information content (PIC) standards ranging from 0 to 0.5 for dominant markers (Botstein et al., 1980) and heterozygosis from binary data obtained with the information of the six markers in Aspidosperma quebracho-blanco populations, tested in the Genes ${ }^{\circledR}$ software (Cruz, 2019).

\begin{tabular}{|c|c|c|c|c|c|c|c|}
\hline Population & Primer & A- & aa & $\mathbf{f}(\mathbf{A})$ & f(a) & $\mathrm{H}=\mathbf{2 p q}$ & PIC \\
\hline PMU & Primer No.7 & 16 & 39 & 0.1579 & 0.8421 & 0.266 & 0.2306 \\
\hline FOR & Primer No.7 & 14 & 41 & 0.1366 & 0.8634 & 0.2359 & 0.2081 \\
\hline FIL & Primer No.7 & 15 & 40 & 0.1472 & 0.8528 & 0.2511 & 0.2195 \\
\hline $\mathrm{COB}$ & Primer No.7 & 19 & 36 & 0.191 & 0.809 & 0.309 & 0.2613 \\
\hline BAQ & Primer No.7 & 28 & 27 & 0.2994 & 0.7006 & 0.4195 & 0.3315 \\
\hline PMU & UBC 808 & 17 & 38 & 0.1688 & 0.8312 & 0.2806 & 0.2412 \\
\hline FOR & UBC 808 & 16 & 39 & 0.1579 & 0.8421 & 0.266 & 0.2306 \\
\hline FIL & UBC 808 & 17 & 38 & 0.1688 & 0.8312 & 0.2806 & 0.2412 \\
\hline $\mathrm{COB}$ & UBC 808 & 17 & 38 & 0.1688 & 0.8312 & 0.2806 & 0.2412 \\
\hline BAQ & UBC 808 & 13 & 42 & 0.1261 & 0.8739 & 0.2205 & 0.1962 \\
\hline PMU & UBC 842 & 10 & 45 & 0.0955 & 0.9045 & 0.1727 & 0.1578 \\
\hline FOR & UBC 842 & 13 & 42 & 0.1261 & 0.8739 & 0.2205 & 0.1962 \\
\hline FIL & UBC 842 & 13 & 42 & 0.1261 & 0.8739 & 0.2205 & 0.1962 \\
\hline $\mathrm{COB}$ & UBC 842 & 13 & 42 & 0.1261 & 0.8739 & 0.2205 & 0.1962 \\
\hline BAQ & UBC 842 & 4 & 51 & 0.037 & 0.963 & 0.0714 & 0.0688 \\
\hline PMU & UBC 856 & 7 & 48 & 0.0658 & 0.9342 & 0.1229 & 0.1154 \\
\hline FOR & UBC 856 & 20 & 35 & 0.2023 & 0.7977 & 0.3227 & 0.2706 \\
\hline FIL & UBC 856 & 14 & 41 & 0.1366 & 0.8634 & 0.2359 & 0.2081 \\
\hline $\mathrm{COB}$ & UBC 856 & 19 & 36 & 0.191 & 0.809 & 0.309 & 0.2613 \\
\hline BAQ & UBC 856 & 18 & 37 & 0.1798 & 0.8202 & 0.2949 & 0.2514 \\
\hline PMU & UBC 857 & 6 & 49 & 0.0561 & 0.9439 & 0.1059 & 0.1003 \\
\hline FOR & UBC 857 & 15 & 40 & 0.1472 & 0.8528 & 0.2511 & 0.2195 \\
\hline FIL & UBC 857 & 8 & 47 & 0.0756 & 0.9244 & 0.1397 & 0.13 \\
\hline $\mathrm{COB}$ & UBC 857 & 12 & 43 & 0.1158 & 0.8842 & 0.2048 & 0.1838 \\
\hline BAQ & UBC 857 & 15 & 40 & 0.1472 & 0.8528 & 0.2511 & 0.2195 \\
\hline PMU & UBC 888 & 7 & 48 & 0.0658 & 0.9342 & 0.1229 & 0.1154 \\
\hline FOR & UBC 888 & 17 & 38 & 0.1688 & 0.8312 & 0.2806 & 0.2412 \\
\hline FIL & UBC 888 & 24 & 31 & 0.2492 & 0.7508 & 0.3742 & 0.3042 \\
\hline $\mathrm{COB}$ & UBC 888 & 23 & 32 & 0.2372 & 0.7628 & 0.3619 & 0.2964 \\
\hline BAQ & UBC 888 & 20 & 35 & 0.2023 & 0.7977 & 0.3227 & 0.2706 \\
\hline
\end{tabular}

The results obtained here point out the importance of conservation units in maintaining the genetic diversity of natural populations, representing a solution for the conservation of A. quebrachoblanco genetic resources, since the damage caused by the anthropization of the Chaco and fields with "espinilho" may result in the loss of habitat and genetic diversity in the studied populations. Therefore, changes in the species conservation status and the creation of germplasm banks of populations from regions with minimal fragmentation effects are necessary, ensuring the conservation and reproduction of plant material as a safety mechanism for species. 


\section{ACKNOWLEDGMENTS}

The authors express gratitude to the Vice-Rector of Research and Postgraduate Studies (Pró-Reitoria de Pesquisa e Pós-Graduação - PROPP) at the Federal University of Mato Grosso do Sul (Notice 109/2019financial support for scientific publications). The authors thank the Genetics Laboratory and the Social and Environmental Studies Laboratory for their technical support (UFMS/CPAN) and the CNPq and Fundect, for the financial aid granted through the Granting Agreement: 202/2014, SIAFEM: 023909, Process 23/200.614/2014. This study was financed in part by the Coordenação de Aperfeiçoamento de Pessoal de Nível Superior - Brasil (CAPES) Finance Code 001 .

\section{BIBLIOGRAPHY}

Aizen, M. A. \& P. Feinsinger. 1994. Forest fragmentation, pollination, and plant reproduction in a Chaco dry forest, Argentina. Ecology 75: 330-351.

Al-Otaibi, S. A. 2008. Genetic variability in mite-resistant honeybee using ISSR molecular markers. Arab Journal of Biotecnology 11: 241-252.

Amom T. \& P. Nongdam. 2017. The Use of Molecular Marker Methods in Plants: A Review. International Journal of Current Research and Review 9(17): 1-7.

Avise, J. C. 2010. Perspective: conservation genetics enters the genomics era. Conservation genetics 11: 665-669.

Bandeira, L. A. M. 1998. A Guerra do Chaco. Revista Brasileira de Política Internacional 41: 162-197.

Barchuk, A. H. \& M. P. Díaz. 1999. Regeneration and structure of Aspidosperma quebracho-blanco Schl. in the Arid Chaco (Córdoba, Argentina). Forest ecology and management 118: 31-36.

Baumann, M.; C. Israel, M. Piquer-Rodríguez, G. GavierPizarro, J. N. Volante \& T. Kuemmerle. 2017. Deforestation and cattle expansion in the Paraguayan Chaco 1987-2012. Regional Environmental Change 17: 1179-1191.

Becker, K. \& H. P. S Makkar. 1999. Effects of tannic acid and quebracho tannin on growth performance and metabolic rates of common carp (Cyprinus carpio L.). Aquaculture 175: 327-335.

Botstein, D.; R. L. White, M. Skolnick \& R. W. Davis. 1980. Construction of a genetic linkage map in man using restriction fragment length polymorphisms. American journal of human genetics 32: 314-331.
Caballero, J.; F. Palacios, F. Arévalos, O. Rodas \& A. Yanosky. 2014. Cambio de uso de la tierra en el Gran Chaco Americano en el año 2013. Paraquaria Natural 2: 21-28.

Caldas, M. M.; D. Goodin, S. Sherwood, J. M. Campos Krauer \& S. M. Wisely. 2013. Land-cover change in the Paraguayan Chaco: 2000-2011. Journal of Land Use Science 10: 1-8.

Chase, M. W. \& H. G. Hills. 1991. Silica gel: an ideal material for field preservation of samples for DNA studies. Taxon 40: 215-220.

Cloutier, D.; M. Kanashiro, A. Y. Ciampi \& D. J. Schoen. 2007. Impact of selective logging on inbreeding and gene dispersal in an Amazonian tree population of Carapa guianensis Aubl. Molecular ecology 16: 797-809.

Costa, D. F. D.; F. D. A. Vieira, C. G. Fajardo \& K. P. T. D. Chagas. 2015. Genetic diversity and ISSR initiators selection in a natural population of mangaba (Hancornia speciosa Gomes) (Apocynaceae). Revista Brasileira de Fruticultura 37: 970-976.

Cruz, C. D. 2019. Programa Genes, análise multivariada e simulação. Biodata - Rede de Pesquisa em Biometria e Estatística DA UFV, Published on the Internet: http://arquivo.ufv.br/dbg/genes/gdown1.htm (access from February 2019).

Cruz, C. D; F. M. Ferreira \& L. A. Pessoni. 2011. Biometria aplicada ao estudo da diversidade genética. $2^{\text {nd }}$ ed. Visconde de Rio Branco: Suprema Gráfica Editora.

Cullen Júnior, L.; H. Borges, J. Lima, N. Campos, T. Beltrame, A. Moscogliato \& E. Ronconi. 2006. Restauração de paisagens e desenvolvimento socioambiental em assentamentos rurais do Pontal do Paranapanema. Agriculturas 3(3): 24-28.

Da Cunha, N. G.; R. J. C. Da Silveira, R. G. Mendes \& M. R. Pereira. 2001. Estudo de solos do Município de Barra do Quarai-RS. Pelotas: Embrapa Clima Temperado.

Damasceno, J. O.; E. A. Ruas, L. A. Rodrigues, C. F. Ruas, E. Bianchini, J. A. Pimenta \& P. M. Ruas. 2011. Genetic differentiation in Aspidosperma polyneuron (Apocynaceae) over a short geographic distance as assessed by AFLP markers. Genetics and Molecular Research 10: 1180-1187.

Darrault, R. O. \& C. Schlindwein. 2005. Limited Fruit Production in Hancornia speciosa (Apocynaceae) and Pollination by Nocturnal and Diurnal Insects. Biotropica 37: 381-388.

Demeke, T. \& R. P. Adams. 1992. The effect of plant polysaccharides and buffer additives of PCR. Biotechniques 12: 332-334.

Dodd, G. L. \& L. A. Donovan. 1999. Water potential and ionic effects on germination and seedling growth of two cold desert shrubs. American Journal of Botany 86(8): 11461153. 


\section{T. S. G. BOTELHO ET AL. Genetic diversity of $A$. quebracho-blanco}

Doyle, J. J. \& E. E. Dickson. 1987. Preservation of Plant Samples for DNA Restriction Endonuclease Analysis. Taxon 36: 715-722.

Faleiro, F. G. 2007. Marcadores genético-moleculares aplicados a programas de conservação e uso de recursos genéticos, Planaltina: Embrapa Cerrados.

Fang, G.; S. Hammar \& R. Grumet. 1992. A quick and inexpensive method for removing polysaccharides from plant genomic DNA. Biotechniques 13: 52-54.

Ferreira, M. E. \& D. Grattapaglia. 1998. Introducción al uso de marcadores moleculares en el análisis genético. Brasília: Embrapa-Cenargen.

Ferreira-Ramos, R.; M. Monteiro, M. I. Zucchi, J. B. Pinheiro, C. A. Martinez, M. A. Mestriner \& A. L. Alzate-Marin. 2011. Microsatellite markers for Aspidosperma polyneuron (Apocynaceae), an endangered tropical tree species. American Journal of Botany e300-e302. DOI: https://doi. org/10.3732/ajb.1100222

Finger, A.; U. Radespiel, J. C. Habel \& C. J. Kettle. 2014. Forest fragmentation genetics: what can genetics tell us about forest fragmentation? In: Global Forest Fragmentation Vol I, pp. 50-68. Zurich: Department of Environmental System Science.

Frankham, R. 2010. Challenges and opportunities of genetic approaches to biological conservation. Biological conservation. 143: 1919-1927.

Freitas, A. D. D. 2008. Aspectos tecnológicos e morfoanatômicos de sementes maduras, plântulas e plantas jovens de Aspidosperma spruceanum Benth. Ex mull. arg. (Apocynaceae). Master tesis, Universidade Federal Rural da Amazônia.

Futuyma, D. J. 1992. Biologia evolutiva. 2nd ed. Ribeirão Preto: SBG.

Galvani, F. R. \& L. R. B. De Moura. 2003. Flora do parque estadual do espinilho-Barra do Quaraí/RS. Revista da FZVA 10: $42-62$.

Gibb, H. H. \& F. Dieter. 2002. Habitat fragmentation in an urban environment: large and small fragments support different arthropod assemblages. Biological Conservation 06: 91-100.

Glémin, S.; E. Bazin \& D. Charlesworth. 2006. Impact of mating systems on patterns of sequence polymorphism in flowering plants. Proceedings of the Royal Society B: Biological Sciences 273: 3011-3019.

Grau, R.; I. Gasparri \& B. T. M. Aide. 2005. Agriculture expansion and deforestation in seasonally dry forests of northwest Argentina. Environmental Conservation 3: 140-148.

Gupta, V. S.; W. Ramakrishna, S. R. Rawat \& P. K. Ranjekar. 1994. (CAC) $)_{5}$ detects DNA fingerprints and sequences homologous to gene transcripts in rice. Biochemical Genetics 32: 1-8.
Guyra Paraguay. Layer Gran Chaco deforestation, Published on the Internet: http://data.globalforestwatch.org/datasets/ 3d668cf0fbcb415bba1ec00bc6263877_5? selectedAtribute= date (access from February 2019).

Hammer, Ø.; D. A. T. Harper \& P. D. Ryan. 2001. PAST: Paleontological Statistics software package for education and data analysis. Palaeontologia Electronica 4: 1-9.

Hamrick, J. L. 2004. Response of forest trees to global environmental changes. Forest Ecology and Management 197: 323-335.

Hamrick, J. L. \& M. J. W. Godt. 1996. Effects of life history traits on genetic diversity in plant species. The Royal Society 351: 1291-1298.

Hamrick, J. L.; D. A. Murawski \& J. D. Nason. 1993. The influence of seed dispersal mechanisms on the genetic structure of tropical tree populations. Vegetatio 107: 281297.

Hansen, M. C.; P. V. Potapov, R. Moore, M. Hancher, S. A. Turubanova, A. Tyukavina \& J. R. G. Townshend. 2013. High-resolution global maps of 21st-century forest cover change. Science 342: 850-853.

Hartl, D. L. \& A. G. Clark. 1997. Principles of population genetics. 4 th ed. Massachusetts: Sinauer associates.

Hasenack, H.; E. Weber, I. I. Boldrini \& R. Trevisan. 2010. Mapa de sistemas ecológicos da ecorregião das savanas uruguaias em escala 1: 500.000 ou superior e relatório técnico descrevendo insumos utilizados e metodologia de elaboração do mapa de sistemas ecológicos. Porto Alegre: Ecology Center of Federal University of Rio Grande do Sul (UFRGS).

Hill, J. K.; M. A. Gray, C. V. Khen, S. Benedick, N. Tawatao \& K. C. Hamer. 2011. Ecological impacts of tropical forest fragmentation: how consistent are patterns in species richness and nestedness? Philosophical Transactions of the Royal Society B: Biological Sciences 366 (1582): 3265-3276.

Howe, H. F. \& J. Smallwood. 1982. Ecology of seed dispersal. Annual Review of Ecology and Systematics 13: 201-228.

Hueck, K. 1955. Bosques chaquenhos e extração de tanino no Brasil. Revista Brasileira de Geografia 17: 343-346.

Hughes, C. E.; R. T. Pennington \& Al. Antonelli. 2013. Neotropical Plant Evolution: Assembling the Big Picture. Botanical Journal of the Linnean Society 171: 1-18.

Jaccard, P. 1908. Nouvelles recherches sur la distribution florale. Bulletin de la Société vaudoise des sciences naturelles 44: 223-270.

Jakovac, C. C.; M. Peña-Claros; T. W. Kuyper \& F. Bongers. 2015. Loss of secondary-forest resilience by land-use intensification in the Amazon. Journal of Ecology 103: 67-77. 
Jørgensen, P. M.; M. H. Nee \& S. G. Beck. 2014. Catálogo de las plantas vasculares de Bolivia. Missouri Botanical Garden Press 127: (1-2).

Kageyama, P. Y.; F. B. Gandara \& L. D. Souza. 1998. Conseqüências genéticas da fragmentação sobre populações de espécies arbóreas. Série Técnica IPEF 12: 65-70.

Katterman, F. R \& V. I. Shattuck. 1983. An effective method of DNA isolation from the mature leaves of Gossypium species that contain large amounts of phenolic terpenoids and tannins. Preparative Biochemistry 13: 347-359.

Kaye, T. N. 1999. From flowering to dispersal: reproductive ecology of an endemic plant, Astragalus australis var. olympicus (Fabaceae). American Journal of Botany, 86: 1248-1256.

Lin, S. \& G. Bernardello. 1999. Flower structure and reproductive biology in Aspidosperma quebracho-blanco (Apocynaceae), a tree pollinated by deceit. International Journal of Plant Sciences 160: 869-878.

Lôbo, D.; T. Leão, F. P. Melo, A. M. Santos \& M. Tabarelli. 2011. Forest fragmentation drives Atlantic forest of northeastern Brazil to biotic homogenization. Diversity and Distributions 17: 287-296.

Löhne, C.; I. C. Machado, S. Porembski, C. Erbar \& P. Leins. 2004. Pollination biology of a Mandevilla species (Apocynaceae), characteristic of NE-Brazilian inselberg vegetation. Botanische Jahrbücher 125(2): 229-243.

Lowry, E. \& E. Lester. 2006. The biogeography of plant reproduction: potential determinants of species' range size. Journal of Biogeography 33: 1975-1982.

Mace, G. M.; N. J. Collar, K. J. Gaston, C. Hilton-Taylor, H. R. Akçakaya, N. Leader-Williams, E. J. Milner-Gulland \& S. N. Stuart. 2008. Quantification of extinction risk: IUCN's system for classifying threatened species. Conservation Biology 6: 1424-1442.

Manel, S; M. K. Schwartz, G. Luikart \& P. Taberlet. 2003. Landscape genetics: combining landscape ecology and population genetics. Trends in Ecology \& Evolution 18: 189-197.

Marcondes-Ferreira, W. \& L. S. Kinoshita. 1996. Uma nova divisão infragenérica para Aspidosperma Mart. (Apocynaceae). Revista Brasileira de Botânica 19: 203214.

Medeiros, M. M.; J. M. Felfini \& M. L. Andréia. 2007. Comparação florístico-estrutural dos estratos de regeneração e adulto em Cerrado sensu stricto no Brasil Central. Cerne 13: 291-298.

Molinari, H. B. \& M. L. Crochemore. 2001. Extração de DNA genômico de Passiflora spp. para análises PCR-RAPD. Revista Brasileira de Fruticultura 23: 447-450.
Montagna, T.; D. K. Ferreira, F. Steiner, F. A. L. Silva, R. Bittencourt, J. Z. Silva, A. Mantovani \& M. S. Reis. 2012. A importância das unidades de conservação na manutenção da diversidade genética de araucária (Araucaria angustifolia) no Estado de Santa Catarina. Biodiversidade Brasileira 2: 18-25.

NAPS Unit Standard Primers. All primers written from 5' to 3', Published on the Internet: https://web.archive.org/web/ 20061002050553/http://www.michaelsmith.ubc.ca/services/ NAPS/Primer_Sets/Primers.pdf (access from February 2019).

Nei, M. 1973. Analysis of gene diversity in subdivided populations. Proceedings of the National Academy of Sciences 70: 3321-3323.

Ng, W. L. \& S. G. Tan. 2015. Inter-Simple Sequence Repeat (ISSR) Markers: Are We Doing It Right? ASM Science Journal 9: 30-39.

Olson, D. M.; E. Dinerstein, E. D. Wikramanayake, N. D. Burgess, G. V. N. Powell, E. C. Underwood, J. A. D'amico, I. Itoua, H. E. Strand, J. C. Morrison, C. J. Loucks, T. F. Allnutt, T. H. Ricketts, Y. Kura, J. F. Lamoreux, W. W. Wetengel, P. Hedao \& K. R. Kassem. 2001. Terrestrial Ecoregions of the World: A New Map of Life on Earth, a new global map of terrestrial ecoregions provides an innovative tool for conserving biodiversity. BioScience 51: 933-938.

Pasig, R. 2005. Origen y Dinámica del Agua Subterránea en el noroeste del Chaco Sudamericano. Tesis Doctoral, Universität Würzburg.

Pollak, E. 1987. On the theory of partially inbreeding finite populations. I. Partial selfing. Genetics 117: 353-360.

Projeto Monitoramento do Desmatamento dos Biomas Brasileiros, Published on the Internet: http://mapas.mma.gov. br/i3geo/datadownload.htm (access from february 2019).

Rajwant, K. K.; K. R. Manoj, K. Sanjay, S. Rohtas \& K. A. Dhawan. 2011. Microsatellite markers: an overview of the recent progress in plants. Euphytica 177: 309-334.

Raymond M. \& F. Rousset. 1995. GENEPOP (version 1.2): Population genetics software for exact tests and ecumenicism. Journal of Heredity 86: 248-249.

Ribeiro, P. C. C., L. C. Pinheiro, R. Domingues, R. C. Forzza, M. A. Machado \& L. F. Viccini. 2013. Genetic diversity of Vriesea cacuminis (Bromeliaceae): an endangered and endemic Brazilian species. Genetics and Molecular Research 12: 1934-1943.

Riveros, F. 2005. The Gran Chaco. FAO (Food and Agriculture Organization) 6: 1-42.

Sahu, S. K.; M. Thangaraj \& K. Kathiresan. 2012. DNA extraction protocol for plants with high levels of secondary metabolites and polysaccharides without using liquid nitrogen and phenol. International Scholarly Research Notices. DOI: https://doi.org/10.5402/2012/205049 
Santana, I. B. B.; E. D. Oliveira, W. S. Soares Filho, R. Ritzinger, E. P. Amorim, M. A. P. C. Costa \& R. F. C. Moreira. 2011. Variabilidade genética entre acessos de umbu-cajazeira mediante análise de marcadores ISSR. Revista Brasileira de Fruticultura 33: 868-876.

Sarwat, M.; M. Singh Negi, M. Lakshmikumaran, A. Kumar Tyagi, S. Das \& P. Shankar Srivastava. 2006. A standardized protocol for genomic DNA isolation from Terminalia arjuna for genetic diversity analysis. Electronic Journal of Biotechnology 9: 86-91.

Schneider, C. A.; W. S. Rasband \& K. W. Eliceiri. 2012. NIH Image to ImageJ: 25 years of image analysis. Nature Methods 9(7): 671-675.

Schneider, M. P. C.; C. G. Batista, D. Carvalho, R. Cerqueira, A. Y. Ciampi, E. V. Franceschinelli, R. Gentile, E. C. Gonçalves, A. D. Grativol, M. T. Nascimento, J. R. Povoa, G. M. P. Vasconcelos, L. H. O. Wadt \& H. C. Wiederhecker. 2003. Genética de Populações Naturais. In: Fragmentação de ecossistemas: causas, efeitos sobre a biodiversidade $e$ recomendações de políticas públicas, pp. 297-315. Brasília: Ministério do meio ambiente.

Schoen, D. J. \& A. H. D. Brown. 1991. Intraspecific variation in population gene diversity and effective population size correlates with the mating system in plants. Proceedings of the National Academy of Sciences 8: 4494-4497.

Schumutz, J. 1960. Phytochemische betrachtungen zum genus Apidosperma. Pharmaceutica Acta Helvetiae 36: 103-118.

Shannon, C. E. 1948. A mathematical theory of communication. Bell System Technical Journal J. 27: 379-423.

Sokal, R. \& C. Michener. 1958. A statistical method for evaluating systematic relationships. University of Kansas Science Bulletin 38: 1409-1438.

Sokal, R. \& F. J. Rohlf. 1995. Biometry: the principles and practice of statistics in biological research. Biometry 451554.

Taubert, F.; R. Fischer, J. Groeneveld, S. Lehmann, M. S. Müller, E. Rödig, T. Wiegand \& A. Huth. 2018. Global patterns of tropical forest fragmentation. Nature 554(7693): 519-522.

Thiers, B. 2020. [Continuously updated] Index Herbariorum: A global directory of public herbaria and associated staff. New York Botanical Garden's Virtual Herbarium. Available from http://sweetgum.nybg.org/science/ih/ (Last accessed: December 2020).
Vallejos, M.; J. N. Volante, M. J. Mosciaro, L. M. Vale, M. L. Bustamante \& J. M. Paruelo. 2015. Transformation dynamics of the natural cover in the Dry Chaco ecoregion: a plot level geo-database from 1976 to 2012. Journal of Arid Environments 123: 3-11.

Vekemans, X. \& O. J. Hardy. 2004. New insights from finescale spatial genetic structure analyses in plant populations. Molecular Ecology 13: 921-935.

Veloso, H. P.; A. L. R. Rangel-Filho \& J. C. A. Lima. 1991. Classificação da vegetação brasileira, adaptada a um Sistema Universal. Rio de Janeiro: Instituto Brasileiro de Geografia e Estatística.

Vieira, F. A. \& D. Carvalho. 2008. Genetic structure of an insectpollinated and bird-dispersed tropical tree in vegetation fragments and corridors: implications for conservation. Biodiversity and Conservation 17: 2305-2321.

Vieira, M. F. \& R. Grabalos. 2003. Sistema reprodutivo de Oxypetalum mexiae Malme (Asclepiadaceae), espécie endêmica de Viçosa, MG, Brasil, em perigo de extinção. Acta Botanica Brasilica 17: 137-145.

Vieira, S. D.; A. R. C. Rabbani, F. Santos, R. Silva-Mann, M. F. Arrigoni-Blank, A. P. N. Prata, L. V. Resende, M. Pasqual \& A. F. Blank. 2014. Molecular characterization of bromeliads from northeast Brazil. Genetics and Molecular Research 13: 9851-9860.

Walker, B.; C. S. Holling, S. R. Carpenter \& A. Kinzing. 2004. Resilience, adaptability and transformability in socialecological systems. Ecology and Society 9(2): 5.

Watson, I. W.; M. Westoby \& A. McR. Holm. 1997. Continuous and episodic components of demographic change in arid zone shrubs: models of two Eremophila species from Western Australia compared to published data on other species. Journal of Ecology 85: 833-46.

Werneck, F. 2011. The diversification of eastern South American open vegetation biomes: Historical biogeography and perspectives. Quaternary Science Reviews 30: 1630-1648.

Wright, S. 1943. Isolation by distance. Genetics 28: 114.

Young, A. \& T. J. Boyle. 2000. Forest fragmentation. In: Forest conservation genetics: principles and practice, pp. 123-134. United Kingdom: Wallingford.

Zak, M. R; M. Cabido \& J. G. Hodgson. 2004. Do subtropical seasonal forests in the Gran Chaco, Argentina, have a future? Biological conservation 120: 589-598.

Zimback, L.; E. S. Mori, P. Y. Kageyama \& A. Hideyo. 2011. Genetic structure of Aspidosperma polyneuron in the State of São Paulo, Brazil. Revista do Instituto Florestal 23: 265-277. 